\title{
Strategies of Cognitive Estrangement in Kim Stanley Robinson's New York 2140
}

\author{
Michał Klata \\ University of Warsaw, Poland
}

This paper seeks to analyse the strategies of cognitive estrangement employed by the science fiction writer and literary scholar Kim Stanley Robinson in his New York 2140 (2017). I argue that the novel was written as a call to action to mitigate the effects of climate change, and rather than being merely a description of a particular vision of the future, provides a comment on the current ecological crisis, mechanisms of history, and human agency. Robinson's unusual position at the intersection of the field of literary production and literature studies allowed him to apply the ideas developed for the analysis of the genre of science fiction in his creative work. The three main thematic areas in the novel are ecology, politics, and history. In each of these, allusions to the present, the past, and literary tradition, characterisation, and narrative structure are used as a means to convey the author's message and sensitise the reader to issues connected with ecology and social justice, painting a realistic, yet hopeful vision where human civilisation carries on despite the consequences of global warming.

\section{Keywords}

Climate change; climate fiction; cognitive estrangement; global warming; literature studies; Robinson; science fiction; utopia

"Why should not art, in its own way, try to serve the great social task of mastering Life?"

Bertolt Brecht

"[I]t may be that science fiction readers will be judged to be among the secret agents of whatever good comes out of our time."

Kim Stanley Robinson 
The purpose of this paper is to analyse the strategies of cognitive estrangement employed by the science fiction writer and literary scholar Kim Stanley Robinson in his New York 2140 (2017). With its many references to our present, history, and literary traditions, this polyphonic novel enters a dialogue with the reader, poses questions regarding ways to deal with the climate crisis and the principles on which the society of late capitalism is based. As testified both by his fiction and interviews, Robinson believes that cognitive estrangement is one of the most important tools at an author's disposal when it comes to presenting his/her ideas to the reader (The Novels of Philip K. Dick 48; "Remarks on Utopia in the Age of Climate Change" 16). It could be argued that the novel chosen for analysis here lends to this particularly well, since the author has been perfecting his craft for many years now, from his "Three Californias" triptych (The Wild Shore 1984, The Gold Coast 1988, Pacific Edge 1990), to the trilogies of Mars (Red Mars 1992, Green Mars 1993, Blue Mars 1996) and "Science in the Capital" (Forty Signs of Rain 2004, Fifty Degrees Below 2005, Sixty Days and Counting 2007). According to Gerry Canavan, the novel could be considered a further step in the development of Robinson's literary output, "comment[ing] on and complicat [ing] the vision of the future espoused by [his] earlier [works]" and his "construction of a huge metatextual history of the future is comparable to the sagas imagined by Asimov and Heinlein" (2017).

Before proceeding to the analysis, it is worth clarifying the concept of cognitive estrangement, a literary technique encouraging the reader to change his/her perspective on the surrounding world. The idea was developed by the literary scholar Darko Suvin, a Yugoslavian émigré who was the editor of Science Fiction Studies in the years 1973-1980 (Science Fiction Studies 2017), and formed the main point of departure for many analyses that appeared in the magazine, eventually also affecting Kim Stanley Robinson. The concept was derived from neo-Marxist theory for the analysis of the political dimension of science fiction poetics, and one of its functions was to legitimise the research in the field in academia (Renault 113).

The notion of "estrangement" was borrowed from the playwright Bertolt Brecht (Verfremdung) and the Russian formalist Victor Shklovsky (остранение). The idea was that art, including literature, can provide the audience with a new perspective of reality, allowing for new cognitive possibilities and courses of action (Suvin 374). As one of the basic elements of the practical realisation of the concept, Darko Suvin proposed the notion of "novum", appropriated from the utopian Marxist Ernst Bloch (Renault 114). In the field of science fiction 
studies, the term usually denotes a new setting, invention, social arrangement, etc., which allows for thought experiments (e.g., what would a society look like if virtual copies of human consciousness could be made?) Suvin's idea that "significant SF is in fact a specifically roundabout way of commenting on the author's collective context" (quoted in Renault 114) opened new research possibilities - visions of the future could now be interpreted as a way of conveying a message about the present. While realising that every metaphor in literature evokes a new reality, different from the lived experience of the authors and their audience, and thus is a kind of novum, he claims that science fiction alone is capable of creating such a profound tension with the reader's world (Renault 114).

Suvin believes that the notion of "cognitivity" allows for differentiating between science fiction and other types of estranged fiction, such as myth, fable, fantasy, fairy tale, or the Romantic pastoral, which present a different perspective but do not reflect on reality in a way which is based on "rational" analysis of facts (Renault 114). The scholar explains how the technique works on the more specific level: "[t]he aliens - utopians, monsters or simply differing strangers - are a mirror to man just as the differing country is a mirror for this world" (Suvin 374). The idea echoes Brecht's explanation of the workings of "estrangement", which he defined in his Short Organon for the Theatre (1948) as "[a] representation which allows for us to recognise its subject, but at the same time makes it seem unfamiliar" (quoted in Suvin 374). At the time, the playwright was working on his Life of Galileo, which premiered in 1943, and it is the approach of the eponymous Renaissance scientist that inspired the notion. Brecht compares "estrangement" to the detached attitude with which "the father of modern science" observed an ordinary chandelier, developing from the analysis of its swing his understanding of the movement of the pendulum (Suvin 374).

Suvin believed that the technique "used by Brecht in a different way, within a still predominantly 'realistic context' [...] has grown into the formal framework of the genre" [of science fiction] (Suvin 375, emphasis in original). Further elaborating on the transformative role of this type of fiction, the scholar explains that "SF sees the norms of any age, including emphatically its own, as unique, changeable, and therefore subject to cognitive glance" (Suvin 375 , emphasis in original). Suvin claims that cognitive estrangement is the basis of science fiction as such, and its main organising principle, seems to be too far-fetched; he especially tries to dismiss the "softer" varieties of the 
genre as mere "regressing into fairy tale", calls space opera "creative suicide", and accuses fantasy of being "just a sub-literature of mystification" (Suvin 375-376). Nevertheless, his ideas might allow for fruitful analysis of works in the genre, especially for those authors who have as one of their main goals to provide commentary on the present.

Indeed, cognitive estrangement is of great importance to Kim Stanley Robinson, as exemplified by the following quote from the revised version of his doctoral dissertation on the novels of Philip K. Dick written under the supervision of Frederic Jameson at the University of California San Diego (The Novels of Philip K. Dick 48):

By frustrating expectations (...) Dick brings us to that quintessentially science fictional moment of cognitive estrangement, wherein we stare at a strange face in a window full of wonder, and then realize the window is a mirror. Moments of estrangement and recognition like this one are the reason science fiction exists.

By way of example, let us analyse the implementation of those principles in the following passage from New York 2140 (Robinson 2017, 501):

She recalled hearing how after Hurricane Katrina hit New Orleans, they had built prison camps faster than medical facilities. They had expected riots and so had put people of color in jail pre-emptively. But that was back in the twentieth century, in the dark ages, the age of fascisms both home and abroad. Since the floods they had learned better, hadn't they?

The puzzling dating of Katrina frustrates expectations of the reader of the novel, which was written mainly for the American market and published only 12 years after the hurricane hit. Surely, it was not "back in the twentieth century, in the dark ages", when they "had put people of colour in jail pre-emptively". Or was it? May the window turn out to be a mirror? The protagonist may have got the century wrong, but it is the reader's task to solve the puzzle, separate fact from fiction, decide to what extent the present-day America suffers from systemic racism, whether "people of colour" are treated fairly by the justice system, and maybe check some facts, e.g., if the state invests more financial resources in prison camps than medical facilities. The final sentence could be interpreted at several levels, as well, leading to more questions for the reader. Had the people in the novel "learned better"? Had the Americans 
of the $21^{\text {st }}$ century "learned better" after Katrina (2005), Sandy (2017), and Harvey (2017)?

For Robinson, it is hard to overestimate the role of helping the readers change their perspective and stimulate their imaginations. Indeed, he believes that literature is of great practical importance, along with the scientific, political, economic, and legal efforts to deal with issues connected with the current ecological crisis. To this end he employs his broad view of utopia as a reflection on a better world rather than a "perfect one, an idea that we could try to make a more just society" ("Afterword: Still, I'm Reluctant to Call This Pessimism" 256), reminiscent of Ernst Bloch's notion of "the Utopian impulse" (Jameson 2). With all the impact of climate change and population overshoot, Robinson claims that human existence will be substantially threatened, and everything within our power should be done to imagine ways to mitigate the effect of these processes and implement practical solutions. He believes that the first of these tasks is also one of the main goals of literature. Since the old solutions led us to global warming, only a radical re-imagination and transformation of society can avert, or mitigate, if it is not too late, a catastrophe ("Remarks on Utopia in the Age of Climate Change" 16). In other words, for humankind "[it] has become a case of utopia or catastrophe, and utopia has gone from being a somewhat minor literary problem to a necessary survival strategy" ("Remarks on Utopia in the Age of Climate Change" 9).

Robinson's first utopia was the last of the novels in the "Three Californias" triptych, Pacific Edge (1990), which presents a vision of a sustainable society inspired by the non-fiction utopian literature of the 1960s ("Remarks on Utopia in the Age of Climate Change" 3) as an alternative to the post-apocalyptic future of The Wild Shore (1984) and hyper-capitalist dystopia of The Gold Coast (1988). The frame narrative of Pacific Edge, which could be interpreted as a tool of cognitive estrangement, puts the status of the utopian vision into doubt. Every chapter starts with comments in italics by Tom Barnard, a character which, apart from the Californian setting, is one of the elements connecting the novels in the series. Connection between the two narrative strands is revealed gradually (e.g., it is only close to the end that the identity of the voice in these fragments is revealed), and finally the reader is left with two possible interpretations: the main narrative is either a utopia written in the dystopian setting of a semi-fascist America of the future, or a continuation of Barnard's story, whose dreams from the time when he was in an internment camp due to his ecological activism have finally come true (Robinson, Pacific Edge 1990). This narrative device forces readers to verify their assumptions 
constantly and approach the status of the presented vision with caution, in the process asking questions about the nature of their reality and possibility of implementing a utopian vision.

While in Pacific Edge global warming is mentioned only in passing, and the main issues are depletion of natural resources, population overshoot, preservation of natural resources, and social justice ideas proposed by alternative economists such as Hazel Henderson and Herman Daly (Robinson, "Remarks on Utopia in the Age of Climate Change" 2), the greenhouse effect becomes the dominant motif of Robinson's series of ecological utopias, "Science in the Capital" (2004, 2005, 2007), where scientific endeavours serve as the main plot engine, and information about the mechanics behind the phenomenon is explained to the reader. According to the author, the trilogy was inspired by his trip to Antarctica in 1995 organised by the National Science Foundation as part of the "Artists \& Writers" programme. Visiting the research stations, he came to the conclusion that as it is based on a search for the truth rather than market principles, science could be one of the ways to enter the path towards utopia ("Still, I'm Reluctant to Call This Pessimism" 244; "Remarks on Utopia in the Age of Climate Change" 3). Another source of inspiration was the discoveries regarding the abrupt process of climate change in the Younger Dryas period (echoed in the idea of "pulses" in New rork 2140 when huge amounts of shelf ice melt in a short time, allowing for a scientifically justified dramatisation of global warming (New York 2140 34)), and his close cooperation with the National Science Foundation ("Remarks on Utopia in the Age of Climate Change" 5). Last but not least, the fact that he is married to a scientist further strengthened the prominence of the idea of an alliance between science and literature, a recurrent motif in Robinson's novels ("Remarks on Utopia in the Age of Climate Change" 245; "Still, I'm Reluctant to Call This Pessimism" 4).

Once the wider public became more familiar with the issues connected with global warming, and the media disseminated the findings and predictions of the subsequent reports by the Intergovernmental Panel on Climate Change, Robinson decided that the time had come for greater literary sophistication and less didacticism. The results were Green Earth (2015), a single novel comprised of fragments of the "Science in the Capital" trilogy, with the scientific comment omitted, and New York 2140 (2017), which presents a vision of the city transformed by the Pulses into a "Super-Venice" ("Remarks in Utopia in the Age of Climate Change" 5).

In New York 2140, the half-drowned city remains the capital of finance. The 
extrapolation of current trends leads to a hyperbole of grotesque proportions, presented not without humour. Lower Manhattan is under water; buildings have their lowest levels submerged. Humanity did not colonise Mars, and AI did not take over the world, because all resources had to be redirected towards energy transformation, building dams (this solution proved only temporary), creating new forms of transport and habitation (floating cities, flying blimpvillages, etc.), and developing carbon-based materials (e.g., "diamond coating") which play the double role of insulating waterproof structures and trapping the carbon taken from the air. Traders rush through the river-alleys in state-of-the-art hydrofoils, making their living betting on indices (symbolising the role of capitalism in the current crisis). One of the characters develops the Intertidal Property Pricing Index, a compound indicator of the worth of the property in flooded areas - in effect, having access to advanced weather models and satellite monitoring allows for hedging against the index, literally making money off human suffering (Robinson, New York 2140). Robinson breaks with apocalyptic narratives, showing a city that has been refusing to part with capitalism and to stop growing, as indicated by the steady influx of refugees and migrants on the one hand, and constructing "superskyscrapers" in Upper Manhattan, which could be also interpreted as a mirror showing the current state of affairs. The same is true for the title of the first chapter: "The Tyranny of Sunk Costs", which apart from being a metaphor and word-play referring to the flooding, is a term for an economic fallacy, whereby cognitive dissonance is reduced by continued investment in an endeavour which has been generating more losses than profit, and is likely to remain doing so (Mankiw, 296-297). Confronted with the explanation of the phenomenon, the reader might start wondering if living in seaside cities, indeed living in late capitalism, is not yet another case of "sunk costs". In the world of New York 2140, the system has been sustained despite its contradictions.

Fast-forwarding the setting 123 years into the future provides Robinson with means of dramatising the processes connected with global warming. This strategy helps the author overcome the challenge identified by Robert Markley, who claimed, when referring to the "Science in the Capital" trilogy, that it is difficult to "[bring] climatological time within the realms of subjective experience" (126). Nevertheless, the visions presented in the two works might be seen as complementary. With its setting in the near future, where a Democrat president finally starts listening to the scientists (by coincidence, a situation not unlike the current one), the trilogy shows practical solutions that can be implemented now to mitigate the effects of climate change, whereas New York 
2140 describes a different timeline, where humankind was forced to undergo some changes to deal with ecological issues and sustain the development of capital, but a bloodless revolution is still needed to stop social injustice. While both works share an interest in two major themes - ecology and politics/ economics (these two areas seem inseparable in Robinson's thought) - in New York 2140, history plays a much more prominent role, being one of the crucial means of cognitive estrangement. Let us now analyse the three areas in greater detail.

Robinson's position on ecology, in New York 2140 and elsewhere can be situated within deep ecology, environmentalism, and ecosocialism, as conceived by Greg Garrard, and does not change much during the course of his career. In the typology of ecological positions proposed by the ecocritic, deep ecology is a view that every living organism needs to be respected equally, and humankind is only one member of the great community of species (Garrard 20-23), whereas environmentalism puts human needs before those of the "environment", of which humanity is a steward (18-20). Robinson believes that we are all part of nature which, as he says in an interview, should be "stud[ied] and thus worshipped as a sacred reality, but it is a reality which we manipulate in order to survive" ("Afterword: Still, I'm Reluctant to Call This Pessimism" 256). While acknowledging the need to protect nature for its own sake, he does not idealise it, as exemplified in the novel in the scene where children are attacked by muskrats, and the reader is set to root for the humans. While acknowledging that it is only natural to care more about our own kind than other species, the author makes a point about homo sapiens being yet another species the boys yell at the creatures, which squeak at them in turn, both sides seriously considering eating each other (Robinson, New York 2140 492). Social ecology (a variety of ecological anarchism) and eco-Marxism claim that capitalism exploits nature and the rest of humankind alike (Garrard 27-30). Acknowledging the need for the structures of the state, Robinson leans towards the latter, as symbolised in the novel by the characters of a policewoman and a senator.

The analysis of Robinson's eco-political stance presented above would not be complete without describing his attitude towards the other positions in Garrard's typology, which he either rejects or is sceptical towards, respectively: cornucopia and ecofeminism. The first claims that there are enough natural resources on Earth and the "invisible hand of the market" is capable of solving all the problems of humankind. The second argues that patriarchy 
exploits nature and women alike (Garrard 16-18). While acknowledging the importance of the feminist case, as symbolised by the introduction of strong female characters (in terms of physical prowess, intelligence, political power, etc.), "the citizen", who could be considered the authorial voice, writes in his essays, intertwining with the main narrative, about a "police state with lots of free speech and freaky lifestyles velvet-gloving the iron fist" (Robinson, New rork 2140141 ), suggesting that he considers the share of resources in society and the case of the poor more important than cultural politics.

It is worth noting that focalisation is one of the main means of conveying political message in the novel. Each chapter is divided into subchapters presenting the story of different characters, and the set remains similar from chapter to chapter (sometimes, however, one character is given voice twice within one chapter, and sometimes they are skipped altogether, etc.) Focalisation is mostly internal, and in the case of all but one protagonist the narration is in the third person. The only character using the first person is the trader Franklin. This decision could be interpreted as a suggestion that in the society of late capitalism only those with sufficient means, who are intimate with the rules that govern the system, can "tell their own story". At the same time, this type of narrative strengthens the persuasive effect of Franklin's journey from cornucopian attitude to a peculiar mixture of entrepreneurial spirit and eco-socialism, encouraging readers to search their feelings constantly in order to decide to which extent they can identify with the hero at any given stage of the novel, thus allowing, hopefully, for a new perspective on their own eco-political attitudes.

One of the crucial political ideas in the novel, and perhaps its most important message, is the idea of bloodless revolution based on a "Piketty tax" and "debtor's strike". The first is a reference to the ideas of Thomas Piketty, who proposed an extremely progressive tax, "cutting" the revenues of the richest above a certain limit (Piketty 76; Robinson New York 2140 151). The second is the idea that a significant portion of society stop paying their debts, bills, rent, etc., thus forcing capitalists to negotiate a new deal. An important factor in the revolt presented in the novel is the "window of opportunity", in the form of a hurricane which hits the US. When buildings are destroyed and the masses are homeless, it is easier to convince them to join the rebellion. Social action results in the stock market bubble bursting, and in a kind of reversal of the 2008 crisis, when the state "bailed out" the banks, the members of the movement press the government to help them but only at the price of nationalising a significant share and introducing radical reforms. According 
to Roberto Ortiz, the solution presented in the novel breaks the usual vicious circle whereby the system of inequalities benefits from catastrophes, as the poor have to accept the conditions imposed by their creditors in order to recover (2020). The question of whether it will solve the problems is left unanswered at the end of the novel supporters of the strike refuse to pay their debts, one of the protagonists wins election to the Senate, and Franklin plans to launch a new product on the market - floating residential platforms that will help solve the problem of homelessness, thus symbolically finishing his journey from a trader benefiting from the destruction of the intertidal zone to an agent of sustainability. The open ending might be interpreted as a suggestion that the moment for action is the eternal "now", and every generation in every time is responsible for the fate of the ones that will follow.

Robinson's idea of "reforms so numerous and systemic that ultimately they will add up to a revolution - to postcapitalism, to utopia - but some generations down the line" ("Remarks on Utopia in the Age of Climate Change" 15 ) is further strengthened by his use of history. One of the important subplots involves the search for the wreck of the Hussar, a ship carrying British gold which sank in New York in 1780. After finding the coins, the two adventurous boys are encouraged by their mentor to find the tomb of Hermann Melville. Another example is a number of references to the crises of the 1930 and the burst of the real estate bubble in 2008. The readers are estranged from their usual view of history by "the citizen", who presents the history of New York and the United States switching back and forth, in a pendulum-like movement forcing the audience to constantly check whether the events presented in those parts of the narrative are our real past or fictional future. Last but not least, it might be argued that the frame narrative with a number of characters from different social spheres, where the trader Franklin is given a first-person voice, and the plot revolves around the idea of cancelation of debts, could be a reference to "The Franklin's Tale" (Chaucer 1994). The overall effect of this immersion in history is the avoidance of the usual apocalyptic narrative in dealing with the disastrous effects of climate change. In other words, the novel suggests that the history of civilisation will be continued, and therefore all the efforts we can make in the present matter.

In summary, in New York 2140 Kim Stanley Robinson employs strategies of cognitive estrangement to comment on the present, and on the historical processes which started in the past and are likely to continue into the future. The novel encourages readers to take a fresh look at the system they live in, and make ecological, economic, and political choices that will aid the survival 
of species, our own included. By showing connection to human history and imagining the future as a continuation of current struggles, Robinson avoids apocalyptical narratives of salvation and doom, showing that an action taken at any point in time matters. New areas will be flooded, desertification will progress, and hurricanes will hit land, but the decisions made today, and from now on, will have impact on sea levels, weather patterns, and the fate of future generations.

\section{Works Cited}

Canavan, Gerry. "Utopia in the Time of Trump". Los Angeles Review of Books 2017, https://lareviewofbooks.org/article/utopia-in-the-time-of-trump/ accessed: 15 March 2017.

Chaucer, Geoffrey. The Franklin's Prologue and Tale from the Canterbury Tales. Cambridge: Cambridge University Press, 1994.

Garrard, Greg. Ecocriticism. London and New York: Routledge, 2004.

Jameson, Fredric. The Desire Called Utopia and Other Science Fictions. London and New York: Verso, 2005.

Mankiw, N. Gregory. Principles of Microeconomics (5th ed.). Boston: Cengage Learning, 2011.

Markley Robert, Kim Stanley Robinson. Urbana, Chicago, and Springfield: University of Illinois Press, 2019.

Ortiz Roberto J., "Financialization, Climate Change, and the Future of the Capitalist World-Ecology: On Kim Stanley Robinson's New York 2140", in: Soundings: An Interdisciplinary fournal vol. 103, no. 2, 2020. University Park, Pennsylvania: Penn State University Press 2020, pp. 264-285.

Piketty, Thomas. Czy można uratować Europę? Kroniki 2004-2012. Warszawa: Wydawnictwo Krytyki Politycznej 2016.

Renault, Gregory. "Science Fiction as Cognitive Estrangement: Darko Suvin and the Marxist Critique of Mass Culture", Discourse, vol. 2, MASS CULTURE ISSUE (Summer, 1980), Detroit: Wayne State University Press 1980, pp. 113-141.

Robinson, Kim S. Blue Mars. New York: Spectra 1996.

--.. Fifty Degrees Below. New York: HarperCollins 2005.

--.. Forty Signs of Rain. New York: HarperCollins 2004.

---. Green Earth. New York: HarperCollins 2015.

---. Green Mars. New York: Spectra 1993.

--. (interview with) "Afterword: Still, I'm Reluctant to Call This Pessimism", 
Green Planets: Ecology and Science Fiction, eds. Gerry Canavan and Kim Stanley Robinson, Middletown, Connecticut: Wesleyan University Press 2014, pp. 243-26o.

---. New York 2140. London: Orbit, 2017.

---. Pacific Edge. New York: Tor, 1990.

---. Red Mars. New York: Spectra, 1992.

--.. "Remarks on Utopia in the Age of Climate Change", Utopian Studies, vol. 27, no. 1 (2016), University Park, Pennsylvania: Penn State University Press, pp. 1-15.

---. Sixty Days and Counting. New York: Spectra, 2007.

---. The Gold Coast. New York: Tor, 1988.

--.. The Novels of Philip K. Dick. Ann Arbor, Michigan: UMI Research Press, 1984 .

---. The Wild Shore. New York: Tor, 1984.

Science Fiction Studies website, https://www.depauw.edu/sfs/masthead.htm, accessed 15 March 2021.

Suvin, Darko. "On the Poetics of the Science Fiction Genre," College English, vol. 34, no. 3 (December 1972), Washington, DC: National Council of Teachers of English; pp. 372-382.

MICHAŁ KLATA is a graduate in sociology (2010) and English Studies (2019) at the University of Warsaw. He is currently working on his $\mathrm{PhD}$ dissertation at the same university on solarpunk and ecological science fiction under the supervision of Professor Dominika Oramus, Ph.D. He specialises in literary and film studies, with a special focus on the social context and the impact of social changes on the narrative genres. His first master's thesis in the field of social sciences contained an analysis of "sociotechnics" as a paradigm of applied sociology, developed by Polish sociologists in 196os as an example of the difficulties in establishing an academic movement proposing the tools for solving social problems by liberally-minded scholars under an oppressive regime, and raising some philosophical questions regarding planned social change. The topic of his second thesis was the representation of James Bond's relations with "Bond girls", with its main focus on shifts in the politics of gender and the impact of feminism. He is co-author of "Socjotechnika a system: o sile kontekstu" (Sociotechnics and the System: The Power of Context), a chapter in "Idee naukowe Adama Podgóreckiego" (The Academic Ideas of Adam Podgórecki) published in 2009, author of the chapter "Functions of the 
Sex Scenes in Netflix's Altered Carbon" in Sex, Death and Resurrection in Altered Carbon (2020), published by McFarland, and an article in the journal Folio: "Dimensions of the Romantic Relationships in Chaucer's Canterbury Tales in the Light of Sternberg's Theory of Love" (2020).

michalklata@student.uw.edu.pl 